\section{Advances and limitations of using satellites to monitor cyanobacterial harmful algal blooms}

\author{
Avanços e limitaçóes para o uso de satélites para monitorar floraçôes de \\ cianobactérias tóxicas
}

Igor Ogashawara $^{1 *}$ (D)

${ }^{1}$ Department of Earth Sciences, Indiana University - Purdue University Indianapolis - IUPUI, 723 W Michigan St, SL118, 46202, Indianapolis, IN, USA

*igorogas@iu.edu, igoroga@gmail.com

Cite as: Ogashawara, I. Advances and limitations of using satellites to monitor cyanobacterial harmful algal blooms. Acta Limnologica Brasiliensia, 2019, vol. 31, e103

Abstract: The use of satellites for monitoring forests is common and well-known practice. However, the operational remote monitoring of water quality from space is still under development. In the United States of America (USA), the use of this type of data is just now being applied to operationally monitor cyanobacterial harmful algal blooms (CHABs). This powerful tool can be used to generate temporal and spatial assessments of CHABs, however the validation of the retrieved information is still a challenge - especially in tropical and equatorial countries. This commentary discusses the advantages and challenges of current initiatives that use Earth Observation data for managing CHABs such as "Lake Erie's HAB Bulletin" and "Project CYAN" - both in the USA. Additionally, it was also discussed the application of remote sensing techniques to monitor CHABs in Brazilian inland waters.

Keywords: satellite; harmful algal blooms; remote sensing.

Resumo: $\mathrm{O}$ uso de satélites para o monitoramento de florestas é uma prática conhecida e comum. Entretanto o monitoramento remoto da qualidade da água ainda é escarça. Nos Estados Unidos da América (EUA), o uso deste tipo de dado está começando a ser utilizado para o monitoramento da floraçấo de cianobactérias tóxicas (FCTs). Essa ferramenta poderosa pode ser utilizada para gerar avaliaçóes espaciais e temporais das FCTs. Entretanto, a falta de informação sobre a sua acurácia ainda é um desafio - especialmente em países tropicais e equatoriais. Esta perspectiva discute as vantagens e desafios de iniciativas atuais que utilizam dados de Observação da Terra para o gerenciamento de FCTs como por o exemplo o "Lake Erie's HAB Bulletin" e o "Project CYAN" - ambos nos EUA. Adicionalmente, também foi discutido a aplicação de técnicas de sensoriamento remoto para o monitoramento de FCTs em águas continentais brasileiras.

Palavras-chave: satélite; floração de algas tóxicas; sensoriamento remoto. 
Environmental monitoring requires regularity and consistency in time and should be extensive in space (Bartram et al., 2014). While traditional monitoring strategies depend on in loco assessment, sampling and laboratorial analysis, the use of remote sensing techniques allow the acquisition of data with temporal and spatial homogeneity (Hadjimitsis \& Clayton, 2009). Satellite imagery has been operationally used to detect changes in land cover, to monitor biodiversity loss and ecosystem dynamics, and to map deforestation and forest degradation (Wulder \& Coops, 2014). However, for water quality monitoring, the operational use of remotely acquired images is under implementation in different countries. Aquatic monitoring studies have been using satellite images to monitor water quality in the ocean (McClain, 2009) and in coastal marine and inland aquatic systems (Mouw et al., 2015). The remote estimation of water quality parameters is based on the quantification of optical properties from each environment (Ogashawara et al., 2017). Based on these optical properties, some operational satellite-based monitoring programs have been implemented to assess cyanobacterial harmful algal blooms (CHABs) in inland waters.

The monitoring of $\mathrm{CHABs}$ is important due to the potential hazards that some species represents for aquatic systems, especially those used for recreation and water supply (Michalak, 2016). Due to the increasing number of events concerning the production of toxins by $\mathrm{CHABs}$, monitoring is an important stage on the implementation of a water governance. Due to the low-cost, constant data acquisition and spatial coverage, there is an increase in the development of tools monitoring $\mathrm{CHABs}$ from satellites images. This perspective comment aims to discuss the full potential of this state-of-the-art technology and its use.

Remote sensing has been used to monitor CHABs worldwide (Simis et al., 2005; Li et al., 2010; Le et al., 2011; Matthews \& Odermatt, 2015). Because chlorophyll- $a$ is the dominant photosynthetic pigment in cyanobacteria (Reinart \& Kutser, 2006), remote sensing of cyanobacteria initially focuses on estimating chlorophyll-a concentration, which is used as a proxy of phytoplankton biomass. However, chlorophyll-a is not an accurate indicator of cyanobacteria because it is a common pigment to almost all phytoplankton groups (Hunter et al., 2009). Therefore, remote sensing studies have evaluated the use of phycocyanin, an accessory pigment unique to cyanobacteria, to remotely estimate cyanobacteria (Simis et al., 2005; Li et al., 2010; Le et al., 2011; Ogashawara et al., 2013; Matthews \& Odermatt, 2015). Operational monitoring of inland water quality parameters via remote sensing, especially phycocyanin or cyanobacteria, has not been fully developed for a regional or global scale application (Michalak, 2016). One of the reasons is due to the different number of water types (Spyrakos et al., 2018) which may vary according to the concentration of phytoplankton (including cyanobacteria), sediments and organic matter. Another factor that could influence the quality of the observed data is the bottom contribution (if the bottom of the reservoir is contributing to the light field in the water column). Thus, different optical properties from different aquatic systems which make some remote sensing algorithms not geographically transferable (Randolph et al., 2008). This means that the performance of an individual model can be strong at one specific location but weak at other locations. Finally, the atmospheric correction is another challenge for the global monitoring of $\mathrm{CHABs}$, once it is important to have an atmospheric correction which can be used globally (Moses et al., 2017).

Additionally, another challenge for the remote estimation of phycocyanin is that models do not totally remove the interference of other phytoplankton pigments or other optically active constituents with the phycocyanin spectral signal (Ruiz-Verdu et al., 2008). Although it is known that phycocyanin has an absorption peak around $620 \mathrm{~nm}$ (Simis et al., 2005; Li et al., 2010), other phytoplankton pigments such as chlorophyll-a and chlorophyll- $b$ also partially absorb at this same wavelength (Simis et al., 2005; Ruiz-Verdu et. al, 2008). Therefore, an accurate remote estimation of phycocyanin requires discriminating the contribution of other pigments to the remote sensing signal at $620 \mathrm{~nm}$. Simis et al. (2005) and Mishra et al. (2013) proposed algorithms to mitigate the interference of chlorophyll- $a$ at $620 \mathrm{~nm}$, but both algorithms considered that the absorptions by Colored Dissolved Organic Matter (CDOM) and detritus were negligible, which is usually not true in inland waters.

To surpass such challenges empirical solutions have been developed to process the remote sensing signal. In the Monteray Bay, California, USA, Palacios et al. (2015) created a spectral library of the hyperspectral reflectance from different species to calculate the chlorophyll-a peak height in red and near infrared spectral range (which is 
mostly associated with phytoplankton and have less influence of CDOM). Thus, the same peak height values were calculated from the hyperspectral airborne data over the study site and were compared to the peak height values from each specie. Xi et al. (2017) used hyperspectral signal to identify different phytoplankton groups based on a spectral library of different species in Lake Taihu, China. In this study, authors processed the hyperspectral signal based on normalization and derivative transformation to differentiate different phytoplankton groups. In these two studies, the effect of other optically active constituents was reduced, however, they rely on the use of hyperspectral sensors which unfortunately there is not such sensor onboard a satellite in the current moment.

Nevertheless, due to the high potential of remote sensing, environmental monitoring programs using this type of technology are under implementation worldwide. One example of a monitoring program is the "Experimental Lake Erie Harmful Algal Bloom Bulletin" developed by the National Oceanic and Atmospheric Administration (NOAA). This program has the goal of monitoring algal blooms and forecast the spreading of HABs in the West part of Lake Erie, one of the Great Lakes of North America, using satellite images (Stumpf $\&$ Dupuy, 2016). In addition, to the HAB bloom identification, the program delineates possible risk areas based on the use of environmental variables to model the lake's currents. Since this project is based only on the Western part of Lake Erie, the geographic location is not an issue for this specific application. However, the pigment masking can generate some uncertainty to the results, especially because this project did not test different models for phycocyanin estimation. Another project that is currently under implementation in the United States is the "CYAN Project", led by United States National Aeronautics and Space Administration
(NASA), NOAA, Environmental Protection Agency (EPA) and United States Geological Survey (EPA, 2017). This project has the main goal of developing an early warning indicator system using historical and current satellite data of freshwater systems in the United States. Because of the geographic extension of this project, geographic transferability will be an issue for its implementation. To solve this problem, the project has been collecting information on optical properties from several inland aquatic systems in order to understand their variability.

In Brazil, studies of remote sensing for monitoring cyanobacteria are still scarce. Table 1 summarizes research articles from the Web of Science database reporting the use of remote sensing for phycocyanin estimation in Brazil. From this list of articles, it was noticed that all articles mentioned phycocyanin, however just four of them measured phycocyanin concentration (Ogashawara et al., 2013, 2014; Cicerelli \& Galo, 2015; Cicerelli et al., 2017), only three modeled phycocyanin from remote sensing measurements (Ogashawara et al., 2013, 2014; Cicerelli et al., 2017) and only two articles applied phycocyanin algorithms to the dataset (Ogashawara et al., 2013, 2014). These observations emphasize the need for phycocyanin research in Brazil, especially because of $\mathrm{CHABs}$ occurrences during the entire year in all regions of the country. Moreover, the lack of optical properties information from tropical and equatorial inland waters leads to the lack of geographic representation of datasets for a global calibration and assessment of remote sensing models. Thus, the acquisition of more datasets from Brazilian inland waters would contribute to advance the field. However, the are some challenges on acquiring data from Brazilian complex waters. Bernardo et al. (2018) showed that surface reflected light (a.k.a. sun glint) can cause up to $30 \%$ of error in the reflectance measurements in Brazilian inland waters. Additionally, authors

Table 1. List of Brazilian research articles (listed on the Web of Science database) and how they interact with PC.

\begin{tabular}{lcccc}
\hline \multicolumn{1}{c}{ Reference } & $\begin{array}{c}\text { Mentioned } \\
\text { phycocyanin? }\end{array}$ & $\begin{array}{c}\text { Measured } \\
\text { phycocyanin? }\end{array}$ & $\begin{array}{c}\text { Modelled } \\
\text { phycocyanin? }\end{array}$ & $\begin{array}{c}\text { Applied } \\
\text { phycocyanin } \\
\text { algorithms? }\end{array}$ \\
\hline Ogashawara et al. (2013) & $\mathrm{X}$ & $\mathrm{X}$ & $\mathrm{X}$ & $\mathrm{X}$ \\
Ogashawara et al. (2014) & $\mathrm{X}$ & $\mathrm{X}$ & $\mathrm{X}$ & $\mathrm{X}$ \\
Cicerelli \& Galo (2015) & $\mathrm{X}$ & $\mathrm{X}$ & - & - \\
Ogashawara et al. (2016) & $\mathrm{X}$ & - & - & - \\
Watanabe et al. (2016) & $\mathrm{X}$ & - & - & - \\
Lins et al. (2017) & $\mathrm{X}$ & - & $\mathrm{X}$ & - \\
Cicerelli et al. (2017) & $\mathrm{X}$ & $\mathrm{X}$ & - \\
\hline
\end{tabular}


also described that the optical complexity of these waters could also contribute to the variance of the remote sensing reflectance. Thus, not only data is needed, but also reliable information about optical properties in the Southern hemisphere.

Future perspectives for the use and development of remote sensing models are related to the development of bio-optical models for CHABs identification. These models could be applied to new monitoring technologies such as the cloud-based platforms for planetary-scale geospatial analysis for image processing (Gorelick et al., 2017). The use of cloud-based technology for monitoring $\mathrm{CHABs}$ via remote sensing can facilitate the distribution of remotely-sensed water quality products to the society. This could also be used as a powerful tool for the management and governance of water resources, especially in countries where water quality monitoring programs are nonexistent. However, not all sensors/satellites have the capability to estimate phycocyanin due to the spectral resolution. Since the remote sensing of water quality is based on narrow spectral features of absorption, sensors with larger spectral bands are not useful for the identification of such features. Due to this limitation, hyperspectral sensors are preferred for the identification of these spectral feature like the absorption of phycocyanin at $620 \mathrm{~nm}$ (Simis et al., 2005; Li et al., 2010; Le et al., 2011). Currently, the Ocean and Land Colour Instrument (OLCI) onboard of Sentinel 3A and 3B is the only sensor/satellite with a spectral band centered at $620 \mathrm{~nm}$. Thus, Sentinel $3 \mathrm{~A}$ and $3 \mathrm{~B}$ are the only satellites that could be used for the precise estimation of phycocyanin, which has been used as a proxy of CHABs (Simis et al., 2005; Ogashawara et al., 2013).

The understating of optical properties in tropical and equatorial inland waters will help the scientific community to build a strong worldwide database which could be used for calibration and validation of global models. Therefore, there is an urgent need for collaboration among scientists from different locations in the world in order to create a database of optical properties from inland aquatic system located in different latitudes. The oceanography community already has such database known as "NASA bio-Optical Marine Algorithm Dataset" (NOMAD), which contain high quality bio-optical global datasets which are suitable for tuning and validating ocean color algorithms (Werdell et al., 2003). The first step for the limnological community was the creation of the Lake Bio-optical Measurements and Matchup
Data for Remote Sensing (LIMNADES) however, there is a lack of data from lakes located in the southern hemisphere (Spyrakos et al., 2018). Thus, the acquisition of data from tropical inland waters is essential for the establishment of such global database which will allow the development of bio-optical algorithms for global waters.

\section{References}

BARTRAM, J., BROCKLEHURST, C., FISHER, M., LUYENDIJK, R., HOSSAIN, R., WARDLAW, T. and GORDON, B. Global monitoring of water supply and sanitation: history, method sand future challenges. International Journal of Environmental Research and Public Health, 2014, 11(8), 81378165. http://dx.doi.org/10.3390/ijerph110808137. PMid:25116635.

BERNARDO, N., ALCÂNTARA, E., WATANABE, F., RODRIGUES, T., CARMO, A., GOMES, A. and ANDRADE, C. Glint removal assessment to estimate the remote sensing reflectance in inland waters with widely differing optical properties. Remote Sensing, 2018, 10(10), 1655. http://dx.doi.org/10.3390/ rs10101655.

CICERELLI, R.E. and GALO, M.L.B.T. Sensoriamento remoto multifonte aplicado na detecção do fitoplâncton em águas interiores. Revista Brasileira de Engenharia Agricola e Ambiental, 2015, 19(3), 259-265. http://dx.doi.org/10.1590/1807-1929/ agriambi.v19n3p259-265.

CICERELLI, R.E., GALO, M. and ROIG, H.L. Multisource data for seasonal variability analysis of cyanobacteria in a tropical inland aquatic environment. Marine and Freshwater Research, 2017, 68(12), 2344-2354. http://dx.doi.org/10.1071/ MF16259.

ENVIRONMENTAL PROTECTION AGENCY EPA. Cyanobacteria Assessment Network (CyAN) [online]. 2017 [viewed 24 Nov. 2017]. Available from: https://www.epa.gov/water-research/cyanobacteriaassessmentnetwork-cyan\#satellite algorithms

GORELICK, N., HANCHER, M., DIXON, M., ILYUSHCHENKO, S., THAU, D. and MOORE, R. Google Earth Engine: Planetary-scale geospatial analysis for everyone. Remote Sensing of Environment, 2017, 202, 18-27. http://dx.doi.org/10.1016/j. rse.2017.06.031.

HADJIMITSIS, D.G. and CLAYTON, C. Assessment of temporal variations of water quality in inland water bodies using atmospheric corrected satellite remotely sensed image data. Environmental Monitoring and Assessment, 2009, 159(1-4), 281-292. http://dx.doi. org/10.1007/s10661-008-0629-3. PMid:19067211.

HUNTER, P.D., TYLER, A.N., GILVEAR, D.J. and WILLBY, N.J. Using remote sensing to aid the assessment of human health risks from blooms of 
potentially toxic cyanobacteria. Environmental Science \& Technology, 2009, 43(7), 2627-2633. http://dx.doi. org/10.1021/es802977u. PMid:19452927.

LE, C., LI, Y., ZHA, Y., WANG, Q., ZHANG, H. and YIN, B. Remote sensing of phycocyanin pigment in highly turbid inland waters in Lake Taihu, China. International Journal of Remote Sensing, 2011, 32(23), 8253-8269. http://dx.doi.org/10.1080/01431161.2 010.533210 .

LI, L., SENGPIEL, R.E., PASCUAL, D.L., TEDESCO, L.D., WILSON, J.S. and SOYEUX, E. Using hyperspectral remote sensing to estimate chlorophyll-a and phycocyanin in a mesotrophic reservoir. International Journal of Remote Sensing, 2010,31(15), 4147-4162. http://dx.doi. org/10.1080/01431161003789549.</jrn>c

LINS, R., MARTINEZ, J.-M., MOTTA MARQUES, D., CIRILO, J. and FRAGOSO, C. Assessment of chlorophyll-a remote sensing algorithms in a productive tropical estuarine-lagoon system. Remote Sensing, 2017, 9(6), 516. http://dx.doi.org/10.3390/ rs9060516.

MATTHEWS, M.W. and ODERMATT, D. Improved algorithm for routine monitoring of cyanobacteria and eutrophication in inland and near-coastal waters. Remote Sensing of Environment, 2015, 156, 374-382. http://dx.doi.org/10.1016/j.rse.2014.10.010.

MCCLAIN, C. A decade of satellite ocean color observations. Annual Review of Marine Science, 2009, 1, 19-42. http://dx.doi.org/10.1146/annurev. marine.010908.163650. PMid:21141028.

MICHALAK, A.M. Study role of climate change in extreme threats to water quality. Nature, 2016, 535(7612), 349-350. http://dx.doi. org/10.1038/535349a. PMid:27443725.

MISHRA, S., MISHRA, D.R., LEE, Z. and TUCKER, C.S. Quantifying cyanobacterial phycocyanin concentration in turbid productive waters: a quasianalytical approach. Remote Sensing of Environment, 2013, 133, 141-151. http://dx.doi.org/10.1016/j. rse.2013.02.004.

MOSES, W.J., STERCKX, S., MONTES, M., DE KEUKELAERE, L. and KNAEPS, E. (2017). Atmospheric correction for inland waters In: Mishra, D.R., Ogashawara, I., and Gitelson, A.A., eds. Biooptical modeling and remote sensing of inland waters. New York: Elsevier, 2017, pp. 1-24. http://dx.doi. org/10.1016/B978-0-12-804644-9.00003-3.

MOUW, C.B., GREB, S., AURIN, D., DIGIACOMO, P.M., LEE, Z., TWARDOWSKI, M., BINDING, C., HU, C., MA, R., MOORE, T., MOSES, W. and CRAIG, S.E. Aquatic color radiometry remote sensing of coastal and inland waters: Challenges and recommendations for future satellite missions. Remote Sensing of Environment, 2015, 160, 15-30. http:// dx.doi.org/10.1016/j.rse.2015.02.001.
OGASHAWARA, I., CURTARELLI, M.P., MISHRA, D.R., ALCANTARA, E.H. and STECH, J.L. Development of a filter for phycocyanin bio-optical estimation. In: Proceedings of the International Geoscience and Remote Sensing Symposium (IGARSS). Quebec: IEEE, 2014, pp. 3862-3865. http://dx.doi. org/10.1109/IGARSS.2014.6947327.

OGASHAWARA, I., MISHRA, D.R. and GITELSON, A.A. Remote sensing of inland waters: background and current state-of-the-art. In D.R. Mishra, I. Ogashawara and A.A. Gitelson, eds. Bio-optical modeling and remote sensing of inland waters. New York: Elsevier, 2017, pp. 1-24. http://dx.doi. org/10.1016/B978-0-12-804644-9.00001-X.

OGASHAWARA, I., MISHRA, D.R., MISHRA, S., CURTARELLI, M.P. and STECH, J.L. A performance review of reflectance based algorithms for predicting phycocyanin concentrations in inland waters. Remote Sensing, 2013, 5(10), 4774-4798. http://dx.doi.org/10.3390/rs5104774.

OGASHAWARA, I., MISHRA, D.R., NASCIMENTO, R.F.F., ALCÂNTARA, E.H., KAMPEL, M. and STECH, J.L. Re-parameterization of a quasianalytical algorithm for colored dissolved organic matter dominant inland waters. International Journal of Applied Earth Observation and Geoinformation, 2016, 53, 128-145. http://dx.doi.org/10.1016/j. jag.2016.09.001.

PALACIOS, S.L., KUDELA, R.M., GUILD, L.S., NEGREY, K.H., TORRES-PEREZ, J. and BROUGHTON, J. Remote sensing of phytoplankton functional types in the coastal oceanfrom the HyspIRI Preparatory Flight Campaign. Remote Sensing of Environment, 2015, 167, 269-280. http:// dx.doi.org/10.1016/j.rse.2015.05.014.

RANDOLPH, K., WILSON, J., TEDESCO, L., LI, L., PASCUAL, D.P. and SOYEUX, E. Hyperspectral remote sensing of cyanobacteria in turbid productive water using optically active pigments, chlorophyll a and phycocyanin. Remote Sensing of Environment, 2008, 112(11), 4009-4019. http://dx.doi. org/10.1016/j.rse.2008.06.002.

REINART, A. and KUTSER, T. Comparison of different satellite sensors in detecting cyanobacterial bloom events in the Baltic Sea. Remote Sensing of Environment, 2006, 102(1-2), 74-85. http://dx.doi. org/10.1016/j.rse.2006.02.013.

RUIZ-VERDÚ, A., SIMIS, S.G.H., DE HOYOS, C., GONS, H.J. and PEÑA-MARTÍNEZ, R. An evaluation of algorithms for the remote sensing of cyanobacterial biomass. Remote Sensing of Environment, 2008, 112(11), 3996-4008. http:// dx.doi.org/10.1016/j.rse.2007.11.019.

SIMIS, S.G.H., PETERS, S.W.M. and GONS, H.J. Remote sensing of the cyanobacterial pigment phycocyanin in turbid inland water. Limnology and 
Oceanography, 2005, 50(1), 237-245. http://dx.doi. org/10.4319/lo.2005.50.1.0237.

SPYRAKOS, E., O'DONNELL, R., HUNTER, P.D., MILLER, C., SCOTT, M., SIMIS, S., NEIL, C., BARBOSA, C.C., BINDING, C.E., BRADT, S., BRESCIANI, M., DALL'OLMO, G., GIARDINO, C., GITELSON, A.A., KUTSER, T., LI, L., MATSUSHITA, B., VICENTE, V.M., MATTHEWS, M.W., OGASHAWARA, I., RUIZ-VERDU, A., SCHALLES, J.F., TEBBS, E., ZHANG, Y. and TYLER, A.N. Optical types of natural waters. Limnology and Oceanography, 2018, 63(2), 846-870. http://dx.doi.org/10.1002/ lno.10674.

STUMPF, R. and DUPUY, D. Experimental lake erie harmful algal bloom bulletin. Washington: NOAA, 2016. Bulletin 28/2016,

WATANABE, F., MISHRA, D.R., ASTUTI, I., RODRIGUES, T., ALCÂNTARA, E., IMAI, N.N. and BARBOSA, C. Parametrization and calibration of a quasi-analytical algorithm for tropical eutrophic waters. ISPRS Journal of Photogrammetry and Remote Sensing, 2016, 121, 28-47. http://dx.doi. org/10.1016/j.isprsjprs.2016.08.009.

WERdEll, P.J., BAILEY, S., FARGION, G., PIETRAS, C., KNOBELSPIESSE, K., FELDMAN, G. and MCCLAIN, C. Unique data repository facilitates ocean color satellite validation. Eos (Washington, D.C.), 2003, 84(38), 379. http://dx.doi. org/10.1029/2003EO380001.

WULDER, M.A. and COOPS, N.C. Make Earth observations open access. Nature, 2014, 513(7516), 30-31. http://dx.doi.org/10.1038/513030a. PMid:25186885.

XI, H., HIERONYMI, M., KRASEMANN, H. and RÖTTGERS, R. phytoplankton group identification using simulated and in situ hyperspectral remote sensing reflectance. Frontiers in Marine Science, 2017, 4, 272. http://dx.doi.org/10.3389/ fmars.2017.00272.

Received: 21 January 2019 Accepted: 09 May 2019 